\title{
CARRYING OUT MUNICIPAL TASKS IN THE SCOPE OF HOUSING STOCK MANAGEMENT - CASE STUDY OF POZNAŃ CITY
}

\author{
Maria Trojanek, assoc. prof., PhD. \\ Department of Investment and Real Estate \\ Poznań University of Economics \\ e-mail:m.trojanek@ue.poznan.pl
}

\begin{abstract}
The municipal real estate stock, including housing, serves as an asset base in the process of carrying out statutory tasks by the municipality. Due to the numerous functions of municipal housing in socioeconomic development and its influence on people's living conditions, it is essential that local governments manage the stock with particular rationality and effectiveness. Management activities differ according to the aim, type and functions of the stock. This paper discusses conditions and potential benefits for the municipality from replacing budgetary units with commercial companies that take over the statutory tasks of municipalities in the field of public social housing and providing the right conditions to enable people's housing needs to be met. Furthermore, the author presents possible financial settlement forms resulting from leasing municipal housing to commercial companies.
\end{abstract}

Key words: management, models of carrying out statutory tasks by municipalities, leasing housing stock, lease rates.

JEL Classification: R30.

Citation: Trojanek M., 2014, Carrying out municipal tasks in the scope of housing stock management - case study of Poznan city, Real Estate Management and Valuation, vol. 22, no. 3, s. 85-92.

DOI: DOI: 10.2478/remav-2014-0030

\section{Introduction}

Managing the municipal housing stock within the chosen policy/ housing strategy is a process mainly oriented at providing conditions for meeting the basic needs of the local community. The municipality, as the owner and administrator of the municipal housing stock, carries out numerous tasks in the field of housing.

Municipalities play many roles when performing tasks, i.e.:

- real estate owners in relation to municipal housing tenants. The primary duty of the municipality is the maintenance of municipal housing. Collected rents should cover the cost of maintenance as well as necessary repairs. Moreover, they should deliver an expected rate of return (yield from invested capital). Nowadays, the rental rates are fixed on a level insufficient to cover maintenance costs in most municipalities,

- owners of dwellings that do not constitute separate premises within a housing association. The municipality participates together with owners of separate premises in the decision processes concerning shared areas, as well as co-finances the maintenance of shared areas, minor repairs and renovations,

- real estate administrators. This function entails organizing on-going maintenance of the entire real estate (cleaning works, electricity and water consumption calculation, repairs of fittings etc.) or single dwellings, 
- real estate managers. This function entails activities taken up for the benefit of the housing association or municipality (if the municipality is the sole owner of the building). The activities involve making decisions and acting on behalf of real estate owners (e.g. organising tenders with the aim of choosing refurbishment and repair operators, companies offering inventory services, entering contracts with utility providers),

- performers of works that are not related to real estate administration.

In market economies which underwent gradual development of real estate markets, three models of municipal (public) housing management can be distinguished:

- model I - the municipality acts as an owner and a real estate manager,

- model II - the municipality creates a unit (entity) responsible for the subject field, yet subordinate to the municipality,

- model III - market way of managing the public housing stock; income from rents has to cover the maintenance of real estates in good condition'1.

Radical changes in managing public real estates in market economies took place at the end of the $70 \mathrm{~s}$ and at the beginning of the $80 \mathrm{~s}$ of the 20th century. The changes resulted from the need to (ZALEWSKI 2006, WOJCIECHOWSKI 2012):

- reduce the cost of stock maintenance,

- provide professional management of the stock,

- separate the fields of owner and user responsibility,

- increase the effectiveness of municipal housing stock management.

There is a great diversity of solutions across European countries, depending on the socio-economic and financial situation of each country.

Managing public assets, irrespective of the economic system, is a process determined by interests (often conflicting) of the following entities:

- users,

- the municipality as a performer of statutory tasks,

- the municipality as an entity aimed at reaching financial goals.

The introduced changes to the management of public assets are the outcome of a broader concept of the New Public Management, which should result in reducing public expenditures and increasing the effectiveness of the sector. Similar effects, though of different scope and volume, may be observed in countries undergoing system changes (e.g. in Poland). It should be noted, that these changes are mainly determined by (BRAL 2004, WOJCIECHOWSKI 2012):

- departing from the dominant role and meaning of public property to the economy,

- perceiving public real estates as assets able to generate financial profits,

- the gradual implementation of market rules,

- the changing role of a public entity from a public goods and service provider to a partner and regulator of the public entity - user relation.

Taking into consideration the fact that municipalities in many countries including Poland are currently operating under significant pressure resulting from acute needs and limited budgets, it should be noted that there is a need for changes in public real estate management.

This paper presents potential benefits resulting from transforming a budgetary entity responsible for carrying out the municipality's statutory tasks related to satisfying housing needs into a commercial company. Furthermore, the author puts forward a proposal for a method of calculating lease rates for the municipal housing stock.

\footnotetext{
${ }^{1}$ See, e.g. A. Maimer, Gospodarowanie nieruchomościami publicznymi - problemy i formy rozwiązań, [in:] Efektywna polityka i administracja. Strategie i instrumenty zarządzania miastami, Published by Związek Miast Polskich and Österreichischer Städtebund, Poznań 2005, pp. 95-101; E. Wojciechowski, Zarządzanie

w samorządzie terytorialnym, Difin, 2012, pp. 198-206; H. Sochacka-Krysiak (ed.), Zarządzanie gospodarką i finansami gminy, SGH Publishing House, Warsaw 2006, p. 30-35; M. Majchrzak, Gospodarka i polityka mieszkaniowa w gminach [in:] A. Zalewski (ed.), Nowe zarządzanie publiczne w polskim samorządzie terytorialnym, SGH Publishing House, Warsaw 2005, p. 207-241; A. Nalepka (ed.), Zarządzanie zasobami mieszkaniowymi w Polsce, Cracow University of Economics, Cracow 2007, p. 81-86.
} 
2. Models of carrying out municipal tasks concerning meeting housing needs in the light of experience of selected municipalities

In the market economies of developed countries, municipalities rarely produce social housing themselves. Instead, they prefer to focus their activity on:

- subsidizing and facilitating construction processes performed by other organizations,

- local planning and local housing policy,

- modernization and redevelopment of housing estates,

- providing shelter for the most vulnerable, while usually outsourcing the management of existing municipal housing stock.

The management may be performed by:

- a unit or a department of the municipal office or a municipal entity (municipal company, organization or budgetary entity),

- an association, a foundation or a cooperative, or other non-profit organizations,

- private companies or private owners within the so called self-management.

The role of municipalities in market-driven economies is to regulate the development of the local housing market. In the economies mentioned above, the role of the owner and service provider was separated over 40 years ago. In Poland, the process of changes is still in progress. In 2010, there were 370 municipal companies and 279 budgetary units operating within the segment of housing. The local government units can outsource public utility works to private companies on the basis of civil-law agreements. The most common agreements cover (GRZYMAŁA 2010):

- management,

- service contracting,

- leasehold,

- franchise,

- concession.

The transformation in the sphere of municipal housing stock management and administration is a complex process resulting from the need to secure public interest. It is carried out with the contribution of private entities that have their own financial criteria and goals (sometimes conflicting with the aims of public bodies).

In the next part of the paper, selected changes within the administration and management of municipal housing in Poland are discussed. It should be noted that possible legal forms of entities carrying out municipal statutory tasks are not subject of the research. Instead, the author focused on presenting solutions similar to the one introduced in Poznań. The sample solutions are:

- Example 1 - the municipality made a contribution in kind of the housing stock to a company;

- Example 2 - the municipality leased its housing stock to a company on the basis of a lease contract. The company pays a fixed rate per $1 \mathrm{~m}^{2}$ to the municipality;

- Example 3 - the municipality leased its housing stock to a company. The company pays a flat rate to the municipality;

- Example 4 - the municipality leased its housing stock to a company, but it incurs the cost of public works the company carries out (from 1 to $1.25 \mathrm{PLN} / \mathrm{m}^{2}$ ) to meet the local society's housing needs. The costs are $40 \%$ lower compared to the period before the changes. Furthermore, the municipality earns a profit from real estate taxes;

- Example 5 - the municipality transferred the housing stock to a company on the basis of an agreement on granting gratuitous usufruct. The company carries out municipal statutory tasks within the housing;

- Example 6 - the municipality leased the housing stock to a company. The lease rate is a nominal sum - its level is fixed at $0.03 \mathrm{PLN} / 1 \mathrm{~m}^{2}$ of usable floor area.

The examples presented above show a great diversification of possible settlements between municipalities and housing companies. This variety results from the scope of tasks that municipalities transfer to companies, the rules companies have to abide by, as well as the ways of securing the completion of tasks.

A wide range of solutions has been introduced in the European Union. For example, in Sweden the lease rate is fixed on market terms (HÜFNER, LUNDSGAARD 2007). Public dwellings are considered to be income-generating assets. Thus, the level of lease rate is equal to yield on long-term bonds $(2.51 \%$ in 2012), but the amount cannot be higher than half of the income generated by the company. 
However, such a solution is possible to adopt only if the rental rates for social housing are marketbased (as in Sweden).

\section{Reasons, goals and benefits of transforming a budgetary entity into a commercial company in Poznań}

The subject of activity for the newly formed company is carrying out the statutory tasks of the municipality in the field of housing, i.e.:

- facilitating the process of meeting housing needs of the local community,

- the production of social housing.

According to the adapted/recommended transformation variant of the local budgetary entity ZKZL (Board of Municipal Housing Resources in Poznań) into a commercial enterprise (hereafter referred to as the Company), the following assumptions were made:

- Poznań city and the new company enter a lease contract concerning the municipal housing stock (the city leases out both housing and commercial real estates),

- Poznań city remains a party to rental agreements,

- Poznań city charges lease on the basis of an agreement with the Company. The collected profit from leasehold is considered an income of the Company,

- the Company renders services to the benefit of the city against payment. The services cover numerous activities related to the proper functioning of the municipal housing stock, and handling plaints claiming compensation for lack of council housing,

- the Company carries out the investment program by taking on financial obligations,

- the City remains the owner of the real estate stock belonging to ZKZL,

- the City is the sole shareholder ( $100 \%$ of shares) in the company.

The last two assumptions are essential to secure the effective completion of housing needs of the local community.

It is assumed that the noticeable effects of transforming ZKZL (budgetary entity) into a Company are, e.g.:

- building more dwellings,

- saving money previously spent on compensations for insufficient provision of council flats,

- increasing the volume of investments,

- providing an opportunity to use financial aid granted by the Housing Foundation (Fundusz Dopłat),

- increasing income to the municipal budget from leasing the subject stock,

- adding a new group to the costs incurred by the city, i.e. costs related to rendering public utility services by the company.

The scope of activity for the Company is the same as ZKZL's (budgetary entity), which focuses particularly on:

- renting and managing own and leased real estates (residential buildings and flats, nonresidential buildings and land),

- carrying out investment projects in the field of municipal housing and purchasing real estates with the aim of social housing provision,

- administering, maintaining and repairing buildings, constructions, dwellings and the adjacent infrastructure to preserve them in good condition,

- rendering general construction services aimed at carrying out statutory tasks of the municipality,

- keeping record of real estates, buildings, constructions and dwellings and the adjacent infrastructure.

Thus the company is supposed to complete statutory tasks of Poznan city in the field of meeting collective housing needs and delivering social housing.

The aims of transforming the budgetary entity ZKZL into a commercial company are:

- the possibility of expanding the new housing stock,

- the possibility of using financial leverage by taking advantage of foreign equity employed to finance construction,

- cutting costs incurred in connection with compensations for insufficient provision of council flats. 


\section{Method of lease calculation for municipal housing - a proposal}

Leasehold is a legal agreement covering granting goods temporarily for use against payment (rent). "In case of a lease agreement the lessor leases a thing to use it and collects benefits for a definite or indefinite period, whereas the lessee is obliged to pay the agreed rent to the lessor," - art. 693 of the Civil Code.

The level of the lease rate depends on numerous factors, particularly on:

- the subject of the lease and its market value,

- the situation on the monetary and credit market,

- the level of market rents for similar real estates,

- the location of the real estate subject to the contract,

- the duration of the lease contract,

- the technical condition of the real estate subject to the lease contract,

- the contract terms.

The parties to the lease contract (lessor and lessee) freely determine the conditions of the agreement and thus secure their interests and rights by making written provisions as to, e.g. mutual commitments, the amount of the lease, and the conditions of payment. What are the rules of fixing rental/lease rate for assets? There are many categories/types of rents/lease, e.g. (BRYX 2009, KONOWALCZUK 2009):

- contract rent - actual rent agreed on by the parties to a contract,

- market rent - equal to current rents paid on the market,

- percentage rent - fixed as a share in sales or rentability,

- base rent - minimum rental/lease rate stipulated in the contract,

- effective rent - equals contract rent reduced by rent relief and any one-time or periodic cash allowances,

- net rent - after the lessor's expenditures have been subtracted,

- minimum flat rate - base or flat rent,

- excess rent - rental rate that exceeds market rate,

- deficit rate - when market rent exceeds contract rent.

The typology presented above proves that there is a wide range of rent types, which means that in the valuation process the valuer needs to carefully study and compare the conditions and terms stipulated in the rental/lease contracts. The solutions related to municipal real estate tasks described in the paper also show great diversity.

Considering the lease subject (its numerous types, various features determining its value, conditions that the lessee has to meet, difficulties with securing public interest etc.), it is noticeable that the solutions presented below are feasible. Apart from a description, the author presents arguments supporting each proposal.

\section{Proposal 1}

The lease rate for assets should reflect market terms.

Assumptions:

- the municipal real estate stock means assets that should generate profits (income),

- by leasing these assets out to other entities, the municipality expects certain profits equal to the yield from long-term securities (bonds).

This solution is not possible to introduce because:

- lease rates diverge from market rates and thus the lessor receives reduced profit,

- market value of the stock is not known,

- there is a conflict between the roles of the municipality, i.e. it is both the owner of the stock and the body that carries out the statutory task (providing conditions for meeting housing needs of

\section{Proposal 2} the local community).

This solution is closely connected to the leasehold rules for the Agricultural Property Stock of the State Treasury. The directive concerning real estate leasehold rules issued by the head of the Agricultural Property Agency says that the rate for buildings and structures amounts to $1.8 \%$ of the book value, yet no less than $0.6 \%$ of the initial value. In the case when the lease rate calculated on this basis diverges considerably from market rates fixed at tenders, it can be set at a different level.

The lease rate cannot be calculated in this way for the leased municipal stock because:

- the city leases out both the housing stock and commercial real estates, 
- the lease calculation method used for the stock belonging to the Agricultural Property Agency applies only to a limited number of real estates or a certain stock.

\section{Proposal 3}

A unique form of long-term leasehold is perpetual usufruct of land. Considering the fact that the annual fee for perpetual usufruct is regulated by law, the lease rate could be calculated as a percentage share of market value of the stock subject to leasehold. In this solution, various real estate types (residential and other/commercial) get different lease rates depending on their use (residential real estates $-1 \%$, commercial ones $-3 \%$, land for similar use - similar rate). The calculation base for lease is the value of real estates subject to leasehold.

\section{Proposal 4}

The lease rate may be calculated as a flat rate for carrying out the municipality's statutory tasks related to:

- creating conditions for the local community to meet its housing needs,

- handling plaints claiming compensation for lack of council housing.

In this proposal, remuneration for both statutory services rendered in the field of housing and the city's (the owner of the stock) share in yield generated by the new company is fixed.

This solution is based on the assumption that the cost of services rendered by the company (stipulated in the contract) reflects market conditions (it is difficult to verify this assumption, yet it is recommended that the cost is compared to other entities' price offers). Furthermore, it is crucial to determine the share of the City in yield generated by the leased assets.

It is suggested that:

- the company's due payment for services rendered on behalf of the city should be equal to the costs of maintaining and administering the stock so far incurred by ZKZL (Board of Municipal Housing Resources in Poznań),

- certain types of costs should be separated, i.e. costs of maintaining and administering residential and commercial real estates,

- the unit cost index should be determined for municipal statutory tasks (cost of maintaining and administering $1 \mathrm{~m}^{2}$ of the stock - for each real estate type separately).

In the light of the data and information gathered, the proposal seems to be feasible with the proviso that some changes may be introduced in the future.

Thus settling accounts between the City and the Company would take the following form:

- the Company charges the City for services,

- the Company transfers to the City a sum of money that comprises: an amount equal to the cost of services rendered (the amount is calculated as a product of the area of the stock and the unit cost index) increased by yield from assets (stock) leased to the Company. The calculation basis for the sum is half the average income generated in three preceding years calculated per $1 \mathrm{~m}^{2}$ usable floor area for a given accounting year.

To sum up, this method of settling accounts between the City and the Company takes $1 \mathrm{~m}^{2}$ of usable floor area of real estate (residential or commercial) as a reference.

The presented proposal of settling accounts between the Company and the City is based on the same method of rent calculation as before. Rental rates for housing usually deviate from market conditions, but they have to be conformable with the current legal regulations. Rents for commercial premises, in turn, are calculated on market terms. Thus the income that the Company is supposed to generate will deviate from the revenue that would otherwise be generated if the rental rates for the leased stock were based on market terms, i.e. on a level that would cover the cost of:

- stock maintenance,

- necessary repairs,

- and bring the owner (i.e. the City) expected income.

The expected income of the Company reflects the current situation, and it is a yield that is agreed on at an income from rents determined on previous conditions/rules.

Thus the amount of income to the budget of the City reflects the generated income and the costs incurred.

The proposed method of settling accounts between the Company and the City (the owner of the stock subject to leasehold) refers to:

- the current legal regulations in the field of determining rents for municipal housing, 
- the municipality's statutory tasks related to satisfying housing needs (the Act on Local Government),

- unique criteria and goals of private and public entities.

The solution ultimately chosen by the Poznan City authorities is based on the last proposal.

\section{Summary}

From the study of applied solutions and proposed models of administering the housing stock both in Polish municipalities and in developed market economies, one can conclude that there is no universal, ready-to-use solution.

The solutions adopted in municipalities rely on the available systems of financing social (in Poland: municipal) housing, and methods of satisfying the housing needs of the local society.

What other benefits apart from those mentioned can the City derive from transforming the budgetary unit into a commercial company?

One should stress the benefits deriving from:

- decreasing the amount of compensation for insufficient provision of council flats; Today such compensation amounts to approx. $11 \mathrm{mln}$ PLN per year. The savings for the City up to the year 2020 are estimated on the level of approx. 60 mln PLN,

- the lack of subsidies from the local budget targeted at housing investments,

- income from real estate tax, approx. $1.8 \mathrm{mln}$ PLN,

- the increase in market value of the housing stock; the Company is supposed to build more than 2,300 flats,

- the improvement of the technical condition of the stock,

- setting aside the accrued sources (income) with the aim of financing tasks related to housing management and administration.

Thus the revenue gained from leasing the housing stock and other assets to the Company is increased by the amount generated by the Company while performing tasks within the scope of producing municipal housing.

Furthermore, it should be noted that some time has to pass before it will be possible for the local government and community to assess whether the adopted form is appropriate and effective. However, looking from the point of view of municipalities that have to perform their statutory tasks, each of the legal structures mentioned (budgetary unit as well as commercial company) is burdened with certain risk.

\section{References}

BRÅL, R.,(ed.), 2004, Ekonomika i zarządzanie miastem (City economics and management), Wrocław University of Economics, Wrocław 2004, p. 36-47.

BRYX, M., 2009, (ed.), Podstawy zarządzania nieruchomościami (Handbook on real estate management), Poltex, Warsaw, p. 188-189.

GRZYMAŁA, Z., 2010, Restrukturyzacja sektora komunalnego w Polsce. Aspekty organizacyjno-prawne $i$ ekonomiczne (The restructuring of municipal sector in Poland. Financial, organizational and legal aspects), SGH Publishing House, Warsaw, 2010, p. 105.

HÜFner, F.,LundsGaARD, J., 2007, The Swedish Housing Market: Better Allocation via Less Regulation, OECD Economics Department Working Papers, No. 559, OECD Publishing, p.15.

KONOWALCZUK, J., 2009, Wycena nieruchomości przedsiębiorstw (Valuation of corporate real estates), C. H. Beck Publishing House, Warsaw , p. 72-75;

MAIMER, A., 2005, Gospodarowanie nieruchomościami publicznymi - problemy $i$ formy rozwiązań (Managing public real estates - problems and solutions), [in:] Efektywna polityka $i$ administracja. Strategie i instrumenty zarzadzania miastami (Effective policy and administration. Strategies and tools within city management), Published by Związek Miast Polskich and Österreichischer Städtebund, Poznań, pp. 95-101.

MAJCHRZAK, M., 2005, Gospodarka i polityka mieszkaniowa w gminach (Municipal management and housing policy) [in:] ZALEWSKI, A., (ed.), Nowe zarzadzanie publiczne w polskim samorzadzie terytorialnym (The New Public Management in the Polish local government), SGH Publishing House, Warsaw, p. 207-241.

NALEPKA, A., 2007 (ed.), Zarzadzanie zasobami mieszkaniowymi w Polsce (Housing stock management in Poland), Cracow University of Economics, Cracow 2007, p. 81-86. 
SOCHACKA-KRYSIAK, H., 2006, (ed.), Zarządzanie gospodarka i finansami gminy (Managing municipal economy and finance), SGH Publishing House, Warsaw 2006, p. 30-35.

WOJCIECHOWSKI, E., 2012, Zarzadzanie w samorzadzie terytorialnym, (Management within the local government), Difin, Warsaw, p.191.

ZALEWSKI, A., 2006, Teoretyczne podstawy zarzadzania gmina (Theoretical aspects of managing a municipality [in:] H. Sochacka (ed.), Zarządzanie gospodarką i finansami gminy (Managing municipal economy and finance), SGH Publishing House, Warsaw, p. 24-30. 